\title{
An Acid Transporting Enzyme in Human Gastric Mucosa
}

\author{
Gaetano Saccomani, Hsuan H. Chang, Anastasios A. Mihas, Sylvia Crago, and \\ GEORGE SACHS, Laboratory of Membrane Biology and Department of \\ Microbiology, University of Alabama in Birmingham, Birmingham, \\ Alabama 35294
}

A B S T R A C T Isolation of a microsomal fraction from human gastric mucosa followed by density gradient centrifugation yielded a vesicular membrane preparation free of mitochondrial markers, containing a $\mathrm{K}^{+}$activated, ouabain-insensitive ATPase with an activity of $20.7 \mu \mathrm{mol} \mathrm{P}_{\mathrm{i}}$ released $/ \mathrm{mg}$ protein per $\mathrm{h}$. Sodium dodecyl sulfate gel electrophoresis showed that the human gastric membrane vesicles contained a major polypeptide of 110,000 daltons, which accounted for $\cong 30 \%$ of the total protein stained and was phosphorylated by $\left[\gamma^{32} \mathrm{P}\right] \mathrm{ATP}$ and dephosphorylated in the presence of $\mathrm{K}^{+}$. Electron microscopy revealed the presence of vesicles with an average size of $0.13 \mu \mathrm{m}$ in diameter. Addition of $0.65 \mu \mathrm{M}$ ATP to this vesicular preparation resulted in the uptake of $17 \mathrm{nmol} \mathrm{H}^{+} / \mathrm{mg}$ protein which was dependent on the presence of $\mathrm{K}^{+}$. The gradient was dissipated by a combination of valinomycin and protonophore after consumption of the ATP. Incubation of fixed human fundic sections or human gastric biopsy with monospecific hog gastric membrane antibody followed by fluorescein-conjugated goat antirabbit $\gamma$-globulin, showed fluorescent staining in the middle portion of the gastric glands. These data indicate that human stomach contains a $\mathrm{H}^{+}$transport ATPase with characteristics similar to those established for lower species.

\section{INTRODUCTION}

The stomach is able to produce and maintain a proton gradient of better than a million-fold. The cell responsible for generation of the gradient, the parietal cell, contains a specialized smooth membrane system, the tubulovesicles, in the apical region, arranged close to the intracellular canaliculus (1). Stimulation of this cell results in a morphological change such that the tubulovesicles convert into microvilli protruding into and expanding the lumen of the intracellular canaliculus $(1,2)$. Studies in various mammals, such as rabbit $(3,4)$,

Received for publication 1 May 1978 and in revised form 26 February 1979. $\operatorname{dog}(5)$, and hog $(6,7)$ have shown that these species contain a $\mathrm{K}^{+}$-activated, $\mathrm{Na}^{+}$-independent ATPase that is also ouabain insensitive both with respect to activity and $\left[{ }^{3} \mathrm{H}\right]$ ouabain binding. ${ }^{1}$ In amphibian mucosa (8), isolated rabbit gastric glands (9) and insulin-inhibited dog gastric secretion (10), $\mathrm{K}^{+}$has been shown to be essential for acid secretion.

This $\mathrm{K}^{+}$-ATPase in hog mucosa has been shown to be present in the parietal cell of the tissue (11) to transport $\mathrm{H}^{+}$in exchange for $\mathrm{K}^{+}(12)$ in an apparently electroneutral fashion (13) and to have a reaction mechanism similar to the better known $\mathrm{Na}^{+}$plus $\mathrm{K}^{+}$ATPase involving a phosphorylated intermediate $(4,5)$.

It was therefore of interest to determine whether this enzyme occurred in human stomach, whether its transport properties were similar to those of lower species, and whether antigenic homology existed between hog and human enzyme.

\section{METHODS}

The gastric membrane vesicles were obtained from the human oxyntic gland mucosa following the method used in hog $(12,14)$. Human stomachs which appeared histologically normal, were obtained at autopsy within $6 \mathrm{~h}$ post-mortem. They were thoroughly washed with ice-cold $0.25 \mathrm{M}$ sucrose solution and then fundus was carefully dissected from the antral and cardiac regions. The mucosa was flooded with $3 \mathrm{M} \mathrm{NaCl}$, and the surface mucosa and most of the superficial cells removed by vigorous wiping with paper towels (15).

The mucosa was scraped from the underlying connective tissue and suspended in ( $\cong 10 \%$ tissue, wt/wt) cold solution of $0.25 \mathrm{M}$ sucrose, $20 \mathrm{mM}$ Tris- $\mathrm{HCl}$ buffer at $\mathrm{pH}$ 7.4. Homogenization was carried out in a tight-fitting Teflon-glass homogenizer with 10 up-down strokes at $2,000 \mathrm{rpm}$. The homogenate was centrifuged at $20,000 \mathrm{~g}$ for $30 \mathrm{~min}$, the resulting pellet washed once, and the combined supernate spun down at $78,000 \mathrm{~g}$ for $1 \mathrm{~h}$ to produce the crude microsomal pellet.

The pellet was resuspended in $0.25 \mathrm{M}$ sucrose- $20 \mathrm{mM}$ Tris$\mathrm{HCl}(\mathrm{pH} 7.4$ ) and the suspension layered on top of a discontinuous gradient consisting of 7\% (wt/vol) Ficoll (Pharmacia Fine Chemicals, Div. of Pharmacia Inc., Piscataway, N. J.) in $0.25 \mathrm{M}$ sucrose-20 mM Tris- $\mathrm{Cl}(\mathrm{pH} \mathrm{7.4)}$ and $30 \%$ (wt/vol) sucrose in $20 \mathrm{mM}$ Tris- $\mathrm{HCl}$ at $\mathrm{pH} 7.4$ and centrifuged at 24,000

${ }^{1}$ Berglindh, T., H. B. Stewart, and G. Sachs. Unpublished observations. 
rpm in an SW 41 (Beckman Instruments, Inc., Spinco Div., Palo Alto, Calif.) rotor for $16 \mathrm{~h}$.

Three fractions were obtained: one at the interface between $0.25 \mathrm{M}$ sucrose and $7 \%$ Ficoll- $0.25 \mathrm{M}$ sucrose designated $\mathrm{H}_{1}$; one at the interface between $7 \%$ Ficoll-0.25 $\mathrm{M}$ sucrose and $30 \%$ sucrose $\left(\mathrm{H}_{2}\right)$; and one as a pellet $\left(\mathrm{H}_{3}\right)$ at the bottom of the gradient. All the manipulations were done at $4^{\circ} \mathrm{C}$.

For transport studies, the fractionation was carried out using unbuffered solutions. Absorbance at $280 \mathrm{~nm}$ was used to locate protein peaks in the gradient fractions, and the Lowry method (16) was used in all other instances. Sucrose density was measured with an Abbé refractometer.

Chemical determination. Substrates used for biochemical assays were obtained from Sigma Chemical Co. (St. Louis, Mo.). $\gamma$-Globulin (human), bovine serum albumin, ovalbumin, and chymotrypsinogen (beef pancreas) were purchased from Schwarz/Mann Div., Becton, Dickinson \& Co. (Orangeburg, N. Y.). $\left[\gamma-{ }^{32}\right.$ P $] A T P$ was obtained from New England Nuclear (Boston, Mass.). All of the chemicals were reagent grade.

$5^{\prime}$-Nucleotidase (AMPase) was measured as previously described (6). ATPase activity was measured in a medium containing $2 \mathrm{mM} \mathrm{MgCl}_{2}, 2 \mathrm{mM}$ ATP (disodium salt) in $40 \mathrm{mM}$ Tris-Cl at $\mathrm{pH} 7.4$, with or without $20 \mathrm{mM} \mathrm{KCl}$. Gramicidin was added in $10 \mu$ l methanol to give a final concentration of $0.1 \mu \mathrm{M}$ with $10 \mu \mathrm{l}$ methanol addition to control tubes. Incubation was carried out at $37^{\circ} \mathrm{C}$ for $15 \mathrm{~min}$ and phosphate released was measured as previously described (6). The $\mathrm{K}^{+}$. stimulated $p$-nitrophenyl phosphatase (pNPPase) ${ }^{2}$ was assayed using a medium containing $6 \mathrm{mM} \mathrm{MgCl}, 6 \mathrm{mM} p$ nitrophenyl phosphate (ditris salt), $40 \mathrm{mM}$ Tris-acetate buffer (pH 7.5) and $20 \mathrm{mM} \mathrm{KCl}$. The $p$-nitrophenol liberated was measured by the method of Torriani (17) after incubation at $37^{\circ} \mathrm{C}$ for $20 \mathrm{~min}$.

Succinate dehydrogenase was measured by the procedure of King (18) and monoamine oxidase was estimated by the method of Tabor et al. (19).

Electron microscopy. The gradient fractions were spun down at $78,000 \mathrm{~g}$ for $1 \mathrm{~h}$. The pellets were fixed with $3 \%$ glutaraldehyde for $1 \mathrm{~h}$ and after removing the glutaraldehyde by washing with $50 \mathrm{mM}$ Tris- $\mathrm{Cl}(\mathrm{pH} 7.4)$, the samples were postfixed in cold $1 \% \mathrm{OsO}_{4}$ in $50 \mathrm{mM}$ cacodylate buffer (pH 7.4). After washing, the pellets were dehydrated with ethanol and embedded in Epon for $40 \mathrm{~h}$ at $60^{\circ} \mathrm{C}$. Thin sections were studied in a Philips EM 300 electron microscope (Philips Electronic Instruments, Inc., Mahwah, N. J.).

Phosphorylation procedures. $40 \mu \mathrm{g}$ of membrane protein was incubated at $4^{\circ} \mathrm{C}$ for $30 \mathrm{~s}$ in a solution containing $0.25 \mathrm{M}$ sucrose, $20 \mathrm{mM}$ Tris-Cl (pH 7.4), $10 \mu \mathrm{M} \mathrm{MgCl}_{2}, 2 \mu \mathrm{M}$ ATP containing $0.2 \mu \mathrm{Ci}\left[\gamma^{-32} \mathrm{P}\right] \mathrm{ATP}$ in the presence or absence of $20 \mathrm{mM} \mathrm{KCl}$, in a total volume of $0.1 \mathrm{ml}$. The labeling reaction was terminated by rapid addition of $1 \mathrm{ml}$ of ice-cold $10 \%$ trichloroacetic acid containing $1 \mathrm{mM} \mathrm{P}_{\mathrm{i}}$ and $0.1 \mathrm{mM}$ ATP.

The samples were filtered through $0.45-\mu \mathrm{m}$ Millipore filters (type HA25, Millipore Corp., Bedford, Mass.) and washed twice with $5 \mathrm{ml}$ cold stop solution. Dried filters were placed in scintillation vials with $10 \mathrm{ml}$ of Aqueous Counting Scintillant (Amersham Corp., Arlington Heights, Ill.) and counted in an LKB 81000 liquid scintillation counter (LKB Instruments, Inc., Rockville, Md.).

For samples which were to undergo electrophoresis, the labeling reaction was stopped with $1 \%$ sodium dodecyl sulfate (SDS)-1\% $\beta$-mercaptoethanol and electrophoresis was performed immediately at $4^{\circ} \mathrm{C}$.

Polyacrylamide gel electrophoresis in SDS. Gel electrophoresis was performed with $5.6 \%$ acrylamide in Tris- $\mathrm{Na}$ acetate buffer system at pH 7.4 containing $0.1 \%$ SDS (20).

${ }^{2}$ Abbreviations used in this paper: pNPPase, $p$-nitrophenyl phosphatase; SDS, sodium dodecyl sulfate.
Suspension of gastric membrane protein at $0.5 \mathrm{mg} / \mathrm{ml}$ was solubilized in $1 \%$ SDS- $1 \% \beta$-mercaptoethanol. The clear sample solution was incubated at $37^{\circ} \mathrm{C}$ for $15 \mathrm{~min}$ to promote reduction of disulfide bounds by $\beta$-mercaptoethanol and then $10 \mu$ l of pyronin $\mathrm{Y}$ solution $(10 \mu \mathrm{g} / \mathrm{ml})$ was added as tracking dye.

$30-40 \mu \mathrm{g}$ of protein was applied to each gel and electrophoresis was carried out at constant current of $5 \mathrm{~mA} / \mathrm{gel}$. Staining and destaining for protein was done as previously described (20).

Gel densitometry was carried out using a Gilford 2400 spectrophotometer (Gilford Instrument Laboratories Inc., Oberlin, Ohio) equipped with a gel scanner at $1.0 \mathrm{~cm} / \mathrm{min}$ scan rate using a slit width of $0.05 \mathrm{~mm}$.

Gels run with ${ }^{32} \mathrm{P}$-labeled membrane were sliced immediately after electrophoresis and each 1.5-mm slice was incubated in $200 \mu \mathrm{l}$ of $60 \%$ hydrogen perioxide at $60^{\circ} \mathrm{C}$ overnight.

The radioactivity was counted in $10 \mathrm{ml}$ of Aqueous Counting Scintillant in an LKB 81000 liquid scintillation counter. Molecular weight estimations were made on gels using $\gamma$-globulin, bovine serum albumin, ovalbumin, and chymotrypsinogen as molecular weight standards.

$\mathrm{H}^{+}$transport studies. The experiments were carried out at $22^{\circ} \mathrm{C}$ in a magnetically stirred vessel and the change of $\mathrm{pH}$ measured by a Radiometer pHM 64 meter (Radiometer Co., Copenhagen, Denmark) with a servorecorder coupled to an REA 112 high sensitivity module. The amplification was so arranged that a deflection of $1 \mathrm{~cm}$ chart width corresponded to a change of $0.01 \mathrm{pH}$ unit (14).

The $\mathrm{pH}$ of all solutions was adjusted to the exact $\mathrm{pH}$ of the experiment before mixing any of the solutions and in general was $\mathrm{pH}$ 6.11. At this $\mathrm{pH}$ no net acid is produced when ATP is hydrolyzed to ADP and $P_{1}(21)$.

Gastric vesicles at final protein concentration of $0.126 \mathrm{mg} / \mathrm{ml}$ were added to $2 \mathrm{ml}$ of a medium containing $5 \mathrm{mM}$ glycyl glycine buffer (pH 6.11), $150 \mathrm{mM} \mathrm{KCl}$, and $2 \mathrm{mM} \mathrm{MgCl}$. After a 5-min preincubation at $22^{\circ} \mathrm{C}, \mathrm{ATP}$ was added to give a final concentration $0.65 \mu \mathrm{M}$. Ionophores such as valinomycin (1 $\mu \mathrm{M})$ and tetrachlorsalicylanilide $(1 \mu \mathrm{M})$ were added in $10 \mu \mathrm{l}$ methanol.

In each experiment, the change in $\mathrm{pH}$ was converted to nanomoles $\mathrm{H}^{+}$uptake by the vesicles by back titration with $10-\mu \mathrm{l}$ aliquots of $10^{-3} \mathrm{~N} \mathrm{HCl}$.

Immunohistochemical studies. Antibody was raised in New Zealand white rabbits against $\mathrm{K}^{+}$-ATPase-enriched hog gastric membranes purified by free-flow electrophoresis as previously described (6). The procedure used for the preparation of this antiserum has been reported elsewhere (11). In brief, rabbits were immunized using $1 \mathrm{mg}$ of purified hog gastric membrane protein suspended in $1 \mathrm{ml}$ of $0.9 \% \mathrm{NaCl}$ solution and mixed with an equal volume of Freund's complete adjuvant.

$\gamma$-Globulin was prepared from the antisera by $50 \%\left(\mathrm{NH}_{4}\right)_{2} \mathrm{SO}_{4}$ precipitation and purified by absorption on insoluble antigen (hog membrane fraction) followed by $\mathrm{pH}$-dependent elution (11). This antibody appeared homogeneous by immunodiffusion (11) and rocket immunoelectrophoresis ${ }^{3}$ and it inhibited the gastric $\mathrm{K}^{+}$-ATPase activity in a concentration-dependent manner (11).

Tissue blocks of human mucosa were fixed in ice-cold $95 \%$ ethanol for $24 \mathrm{~h}$. After being embedded in paraffin, the specimens were cut into 4- to 5- $\mu \mathrm{m}$ thick serial sections. The paraffin was removed in cold xylene and the human gastric sections were equilibrated in phosphate-saline buffer ( $\mathrm{pH} \mathrm{7.4)}$ for 30 min. Sections were processed for hematoxylin and eosin stain-

${ }^{3}$ Saccomani, G., H. F. Helander, S. Crago, H. H. Chang, D. W. Dailey, and G. Sachs. Manuscript submitted for publication. 


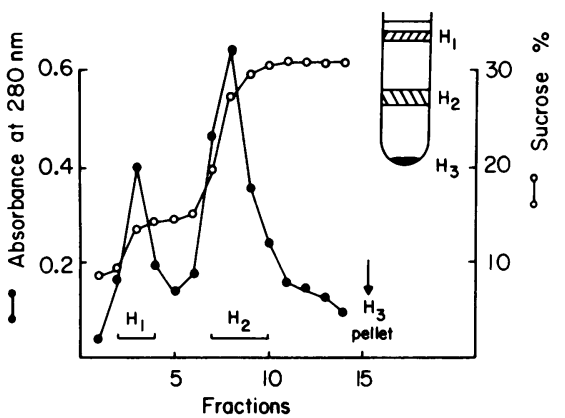

FIGURE 1 Fractionation of human gastric microsomes by density gradient centrifugation. Microsomal pellet was resuspended in $0.25 \mathrm{M}$ sucrose $-20 \mathrm{mM}$ Tris-Cl $(\mathrm{pH} 7.4)$ and fractionated by discontinuous density gradient centrifugation consisting of $7 \%$ (wt/vol) Ficoll in $0.25 \mathrm{M}$ sucrose $-20 \mathrm{mM}$ Tris-Cl and $30 \%$ (wt/vol) sucrose in $20 \mathrm{mM}$ Tris-Cl layers. Protein distribution was determined by measuring the absorbance at $280 \mathrm{~nm}$ and sucrose density was determined by an Abbé refractometer. The inset shows a schematic representation of a density gradient centrifugation tube after $16 \mathrm{~h}$ spinning at $24,000 \mathrm{rpm}$ in an SW 41 rotor. $\mathrm{H}_{1}$ represents the membrane fraction banding at density $1.05 ; \mathrm{H}_{2}$ membrane binding at density 1.11 and $\mathrm{H}_{3}$, membrane pellet.

ing, and for immunofluorescence experiments, the method of indirect staining was used (22).

Human fundic sections were flooded with $100 \mu \mathrm{l}$ of monospecific hog gastric membrane antibody solution (1.5-3.0 $\mathrm{mg} / \mathrm{ml}$ ) and incubated in moist atmosphere at room temperature for $45 \mathrm{~min}$. These sections were washed twice with $0.1 \mathrm{M}$ phosphate buffer (pH 7.4) containing $0.15 \mathrm{M} \mathrm{NaCl}$ and then treated with fluorescein isothiocyanate-conjugated goat antirabbit $\gamma$-globulin (Behring Diagnostics, American Hoechst Corp., Somerville, N. J.) reconstituted in $1.0 \mathrm{ml}$ of sterile distilled water, using $100 \mu \mathrm{l}$ of a 1:10 dilute solution. After a further 45-min incubation at room temperature, the fundic sections were washed with phosphate-saline buffer overnight and mounted in buffered elvanol.

The stained sections were examined with a Leitz fluorescence microscope (E. Leitz, Inc., Rockleigh, N. J.). Control sections were put through the same procedure using sera from nonimmunized rabbit.

\section{RESULTS}

Isolation and composition of the human gastric membrane vesicles. Gastric mucosa contains five major cell types: surface, neck, parietal, peptic, and endocrine cells. Flooding the mucosa with hypertonic $\mathrm{NaCl}$ results in selective removal of most of the surface and neck cells, leaving the parietal and peptic cells. Homogenization and differential centrifugation of the homogenate results in a microsomal pellet which can be further fractionated by density gradient centrifugation. Using Ficoll-sucrose discontinuous gradient the gastric microsomes are separated into three fractions (Fig. 1) with peaks of protein at densities of $1.05\left(\mathrm{H}_{1}\right)$, $1.11\left(\mathrm{H}_{2}\right)$, and a pellet $\left(\mathrm{H}_{3}\right)$ at the bottom of the tube.

As shown in Table $\mathrm{I}$, these fractions contain various enzyme activities with different distribution and relative enrichment. The $5^{\prime}$-nucleotidase is mainly localized in the $\mathrm{H}_{1}$ fraction although activity is also associated with $\mathrm{H}_{2}$ fraction. $\mathrm{Mg}^{++}$-dependent, $\mathrm{K}^{+}$-stimulated ATPase seems equally distributed in both $\mathrm{H}_{1}$ and $\mathrm{H}_{2}$ fractions, but addition of a $\mathrm{K}^{+}$-ionophore such as gramicidin clearly increased the $\mathrm{K}^{+}$-ATPase activity giving a 19-fold enrichment of ionophoretic stimulation in $\mathrm{H}_{1}$ when compared to the total homogenate. The ionophoretic stimulation disappears with dilution of the fraction by hypotonic solutions, optimal conditions for assay of the ionophore effect being solutions of identical tonicity to the original isolation medium.

$\mathrm{K}^{+}$-pNPPase exhibits maximal activity in $\mathrm{H}_{2}$ fractions but significant activity was also detected in $\mathrm{H}_{1}$.

In both fractions, the ATPase and pNPPase activities were $\mathrm{Na}^{+}$independent and ouabain insensitive.

$\mathrm{Mg}^{++}$-ATPase, although present in all gradient fractions, shows maximal enrichment in $\mathrm{H}_{3}$ and it seems to co-purify with the mitochondrial enzyme markers such as succinate dehydrogenase and monoamine oxidase with $>90 \%$ of their activity present in this fraction (Table II). The 'basal' $\mathrm{Mg}^{++}$-ATPase and $\mathrm{K}^{+}$-pNPPase ac-

TABLE I

Purification of Gastric Microsomal Membranes from Human Fundus*

\begin{tabular}{lccccc}
\hline \multicolumn{1}{c}{ Fraction } & mg Protein & 5'-AMPase & Mg ${ }^{++}$-ATPase & K+-ATPaset & $\mathrm{K}^{+}$-pNPPase \\
\hline Total homogenate (3) & 190.3 & 0.4 & 3.3 & $1.1(1.2)$ & 1.4 \\
Crude microsomes (4) & 14.7 & 2.2 & 16.8 & $3.7(4.3)$ & 3.3 \\
H $_{1}$ Gradient membrane (4) & 1.9 & 3.5 & 12.5 & $8.4(20.7)$ & 4.5 \\
H $_{2}$ Gradient membrane (4) & 2.8 & 2.5 & 21.4 & $6.4(9.0)$ & 9.9 \\
H $_{3}$ Gradient membrane $(2)$ & 9.1 & 0.6 & 33.5 & $1.7(0.9)$ & 1.8 \\
\hline
\end{tabular}

Values in parentheses indicate the $\Delta \mathrm{K}^{+}$-ATPase activity in the presence of $0.1 \mu \mathrm{M}$ gramcidin.

* Activities are expressed in micromoles of $\mathrm{P}_{\mathrm{i}}$ or $\boldsymbol{p}$-nitrophenal per milligram protein per hour.

$\$ \mathrm{~K}^{+}$-ATPase activity is expressed as the difference between the total $\mathrm{K}^{+}$-stimulated ATPase and the basal $\mathrm{Mg}^{++}$-ATPase.

$\S \mathrm{H}_{3}$ pellet obtained by density gradient centrifugation was resuspended in $2 \mathrm{ml}$ of $20 \mathrm{mM}$ Tris-Cl buffer and protein determination and enzyme assays were carried out as described in Methods. 
TABLE II

Mitochondrial Enzyme Markers of the Gastric Membranes for Human Fundus*

\begin{tabular}{lcc}
\hline \multicolumn{1}{c}{ Fractions } & Succinate dehydrogenase & Monoamine oxidase \\
\hline & Ulmg protein $\times 10^{-2}$ & U/mg protein \\
Total homogenate (3) & 1.59 & 8.76 \\
Microsomal pellet (3) & 2.47 & 10.20 \\
$\mathrm{H}_{1}$ Gradient membrane (3) & $\mathrm{ND}$ & $\mathrm{ND}$ \\
$\mathrm{H}_{2}$ Gradient membrane (3) & 0.92 & 1.84 \\
$\mathrm{H}_{3}$ Gradient membrane (2) & 4.96 & 4.36 \\
\hline
\end{tabular}

ND, not detectable.

* The number of different preparations used to arrive at the mean activities is given in parentheses.

tivities were not stimulated by gramicidin, indeed in some instances these activities were slightly inhibited.

Electrophoretic analysis of membrane proteins. To analyze the polypeptide composition of the human gas-

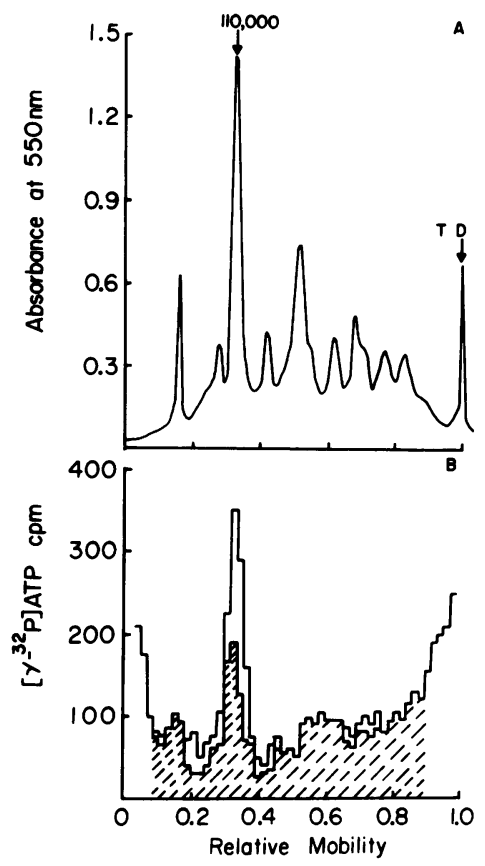

FIGURE 2 SDS gel electrophoresis. (A) Optical density measurement of $\mathrm{H}_{1}$ membrane fraction subjected to SDS gel electrophoresis in $5.6 \%$ polyacrylamide. Approximately $40 \mu \mathrm{g}$ of solubilized membrane protein was applied to the gel. Gel was stained with Coomassie Blue, destained and scanned at $550 \mathrm{~nm}$. Molecular weight was estimated by calibration of identical gels with standard proteins (TD, tracking dye). (B) Phosphorylation pattern of $\mathrm{H}_{1}$ membrane fraction. $40 \mu \mathrm{g}$ of membrane protein was phosphorylated in a medium consisting of $0.25 \mathrm{M}$ sucrose, $20 \mathrm{mM}$ Tris-Cl (pH 7.4), $10 \mu \mathrm{M}$ $\mathrm{MgCl}_{2}, 2 \mu \mathrm{M}$ ATP with $0.2 \mu \mathrm{Ci}$ of $\left[\gamma^{32} \mathrm{P}\right] \mathrm{ATP}$, at $4^{\circ} \mathrm{C}$ for $30 \mathrm{~s}$ with or without the addition of $20 \mathrm{mM} \mathrm{KCl}$. Membranes were solubilized in SDS- $\beta$-mercaptoethanol and subjected to gel electrophoresis. Details are given in Methods. ( $\square$ ) ${ }^{32} \mathrm{P}$ distribution in the absence of $20 \mathrm{mM} \mathrm{KCl},(\square){ }^{32} \mathrm{P}$ distribution in the presence of $20 \mathrm{mM} \mathrm{KCl}$. tric membrane, fractions solubilized in $1 \%$ SDS- $\beta$-mercaptoethanol were subjected to acrylamide gel electrophoresis. Fig. 2A shows a spectrophotometric scan of $\mathrm{H}_{1}$ fraction separated in $5.6 \%$ acrylamide system. At least nine protein bands can be observed, with a molecular weight ranging between 180,000 and 31,000 daltons. A major polypeptide with a molecular weight of 110,000 accounts for $\cong 30 \%$ of the total protein as determined by Coomassie Blue staining and quantitative densitometry.

Membrane phosphorylation. Since it has been shown in other species that the gastric ATPase has what could be a phosphorylated intermediate $(4,5)$ it was of interest to see if the human gastric $\mathrm{H}_{1}$ fraction contained an analogous reaction.

Incubation of this fraction with $\left[\gamma^{32} \mathrm{P}\right] \mathrm{ATP}$ in the presence of $10 \mu \mathrm{M} \mathrm{Mg}^{++}$showed that the level of phosphorylation was $130 \mathrm{pmol} / \mathrm{mg}$ of membrane protein. This label was partially sensitive to $\mathrm{KCl}$ with a reduction of $39 \%$ of the ${ }^{32} \mathrm{P}$ label when membranes were phosphorylated in the presence of $20 \mathrm{mM} \mathrm{KCl}$.

When phosphorylation reaction was stopped by the addition of SDS $-\beta$-mercaptoethanol and solubilized membrane protein subjected to electrophoresis at $\mathrm{pH}$ 7.4 , at $4^{\circ} \mathrm{C}$, a characteristic distribution of radioactivity was seen.

Fig. 2B illustrates a typical ${ }^{32} \mathrm{P}$ profile obtained by electrophoresis of the $\mathrm{H}_{1}$ fraction.

It can be seen that the major 110,000-dalton polypeptide is phosphorylated in the presence of $\mathrm{Mg}^{++}$ alone and the magnitude of the label is significantly diminished by the addition of $\mathrm{KCl}$.

Substantial amounts of radioactivity migrate in a broad zone towards the tracking dye, but the label was insensitive to $\mathrm{K}^{+}$addition. Published electrophoretograms of phosphorylated ATPase preparation shows a similar distribution of ${ }^{32} \mathrm{P}(5)$. This probably reflects the progressive hydrolytic release of covalently bound phosphate from the phosphoprotein component during electrophoresis at $\mathrm{pH} \mathrm{7.4,} \mathrm{and} \mathrm{hence} \mathrm{the} \mathrm{presence} \mathrm{of}$ free inorganic ${ }^{32} \mathrm{P}$ toward the anodic end of the gel. 


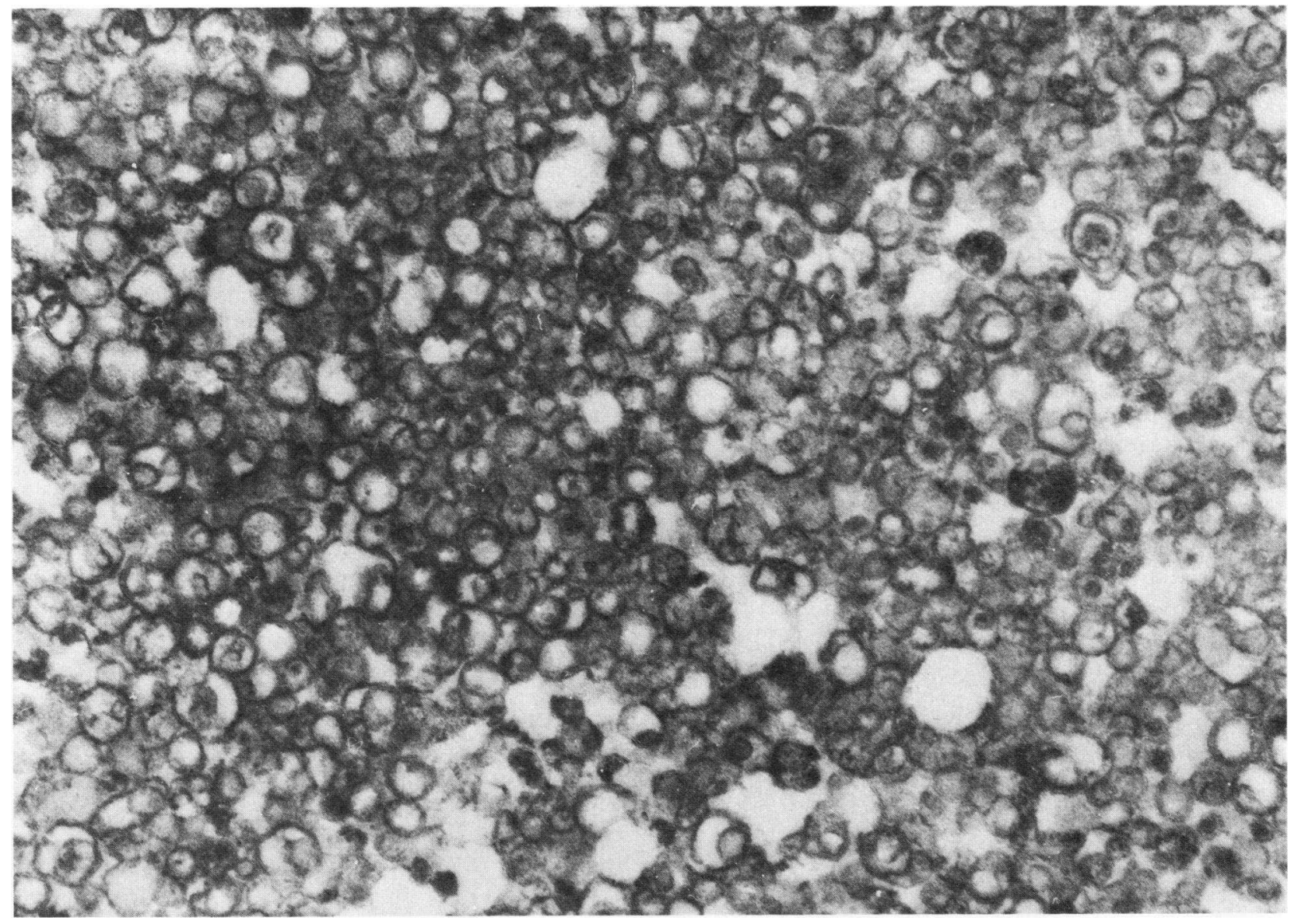

FIGURE 3 Electron microscopy. Electron micrograph of the light $\left(\mathrm{H}_{1}\right)$ membrane fraction used in this study. These membranes are in the large part vesicular with inclusion of some granular content. $(\times 40,500)$.

Electron microscopy. An electron micrograph of the $\mathrm{H}_{1}$ membrane fraction is shown in Fig. 3. The fraction is almost entirely composed of vesicles with an average diameter of $0.13 \mu \mathrm{m}$, and some of the vesicles appear to have a granular content.

$\mathrm{H}^{+}$uptake by the gastric vesicles. The addition of human gastric vesicles to the standard $\mathrm{KCl}$ medium results in no change of $\mathrm{pH}$ until the addition of ATP indicating either equal $\mathrm{K}^{+}$and $\mathrm{Cl}^{-}$permeability or the absence of a $\mathrm{K}^{+}$or $\mathrm{H}^{+}$conductance.

The addition of ATP (final concentration $0.65 \mu \mathrm{M}$ ) to the $\mathrm{H}_{1}$ fraction preincubated for $5 \mathrm{~min}$ in the standard $\mathrm{KCl}$ medium, produced a total of $17 \mathrm{nmol}$ of $\mathrm{H}^{+}$ transport/mg protein with an initial uptake rate of $\cong 4$ $\mathrm{nmol} \mathrm{H}^{+} / \mathrm{mg}$ of protein per $0.1 \mathrm{~min}$ and a $\mathrm{t}_{\max }$ (time required to reach transport plateau) of $3 \mathrm{~min}$ (Fig. 4).

These results were quantitatively different compared to purified hog gastric vesicles. As shown in Table III, a more rapid $\mathrm{H}^{+}$uptake $\left(16.3 \mathrm{nmol} \mathrm{H}^{+} / \mathrm{mg}\right.$ protein per $6 \mathrm{~s})$ a shorter $t_{\max }(<1 \mathrm{~min})$ and twice the total

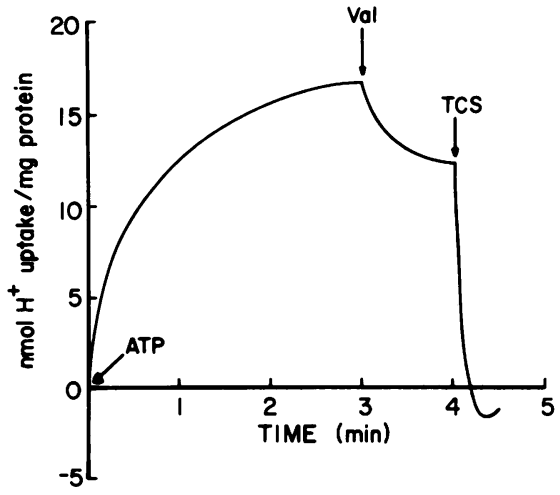

Figure $4 \mathrm{H}^{+}$uptake by human gastric vesicles. Vesicles at final protein concentration of $0.126 \mathrm{mg} / \mathrm{ml}$ were added to $2 \mathrm{ml}$ of a solution containing $5 \mathrm{mM}$ glycyl glycine buffer $(\mathrm{pH}$ 6.11) $150 \mathrm{mM} \mathrm{KCl} ; 2 \mathrm{mM} \mathrm{MgCl}{ }_{2}$ at $25^{\circ} \mathrm{C}$ followed by addition of $0.65 \mu \mathrm{M}$ ATP (final concentration). At times indicated valinomycin (val) and tetrachlorsalicylanilide (TCS) were added. 
TABLE III

Proton Uptake by the Gastric Vesicles

\begin{tabular}{|c|c|c|c|}
\hline $\begin{array}{c}\text { Gastric } \\
\text { membrane } \\
\text { vesicles* }\end{array}$ & Initial uptake rate & Total $\mathrm{H}^{+}$transport & $t_{\max }$ \\
\hline & $\mathrm{nmol} \mathrm{H}^{+} / \mathrm{mg}$ protein $/ 6 \mathrm{~s}$ & nmol $\mathrm{H}^{+} / m g$ protein & $\min$ \\
\hline $\operatorname{Man}\left(\mathrm{H}_{1}\right)$ & 3.7 & 16.8 & 3 \\
\hline $\operatorname{Hog}(G I) \downarrow$ & 16.3 & 33.1 & 1 \\
\hline
\end{tabular}

* All membrane vesicles were preincubated in $150 \mathrm{mM} \mathrm{KCl}$, $2 \mathrm{mM} \mathrm{MgCl} 2,5 \mathrm{mM}$ glycyl glycine buffer ( $\mathrm{pH} \mathrm{6.11)}$ for $5 \mathrm{~min}$ at $22^{\circ} \mathrm{C}$ before addition of ATP. (Final concentration $0.65 \mu \mathrm{M}$ ). \$ GI indicates the hog gastric membrane fraction purified by density gradient centrifugation as previously reported $(12,14)$.

nanomoles of $\mathrm{H}^{+}$transport were observed in this system. However, in both types of vesicles, the proton gradient was partially dissipated by the addition of $1 \mu \mathrm{M}$ valinomycin and completely dissipated by the subsequent addition of $1 \mu \mathrm{M}$ tetrachlorsalicylanilide as previously noted $(12,23)$. Complete dissipation of the $\mathrm{H}^{+}$gradient was also achieved by tetrachlorsalicylanilide followed by valinomycin.

Antibody studies. Hog purified anti- $\mathrm{K}^{+}$-ATPase antibody which has been shown to cross-react with the parietal cells of other species such as rat $(11)^{3}$ was used to stain human gastric mucosa sections by the indirect immunofluorescence technique. The staining pattern is illustrated in Fig. 5. The majority of the fluorescence is confined to the middle third region of the gastric gland where the majority of the parietal cells are present and can be assumed to be localized to the parietal cells based on their shape and location (Fig. 6). Human fundic section stained with hematoxylin and eosin is shown in Fig. 7. $\gamma$-Globulin obtained from sera of control rabbits did not react with human tissue, nor was any reaction detected with the antrum.

\section{DISCUSSION}

The mechanism of $\mathrm{H}^{+}$secretion has been intensively investigated in animals and man. In the latter, however, for obvious reasons only stimulatory pathways have been investigated. Recent investigations in vari-

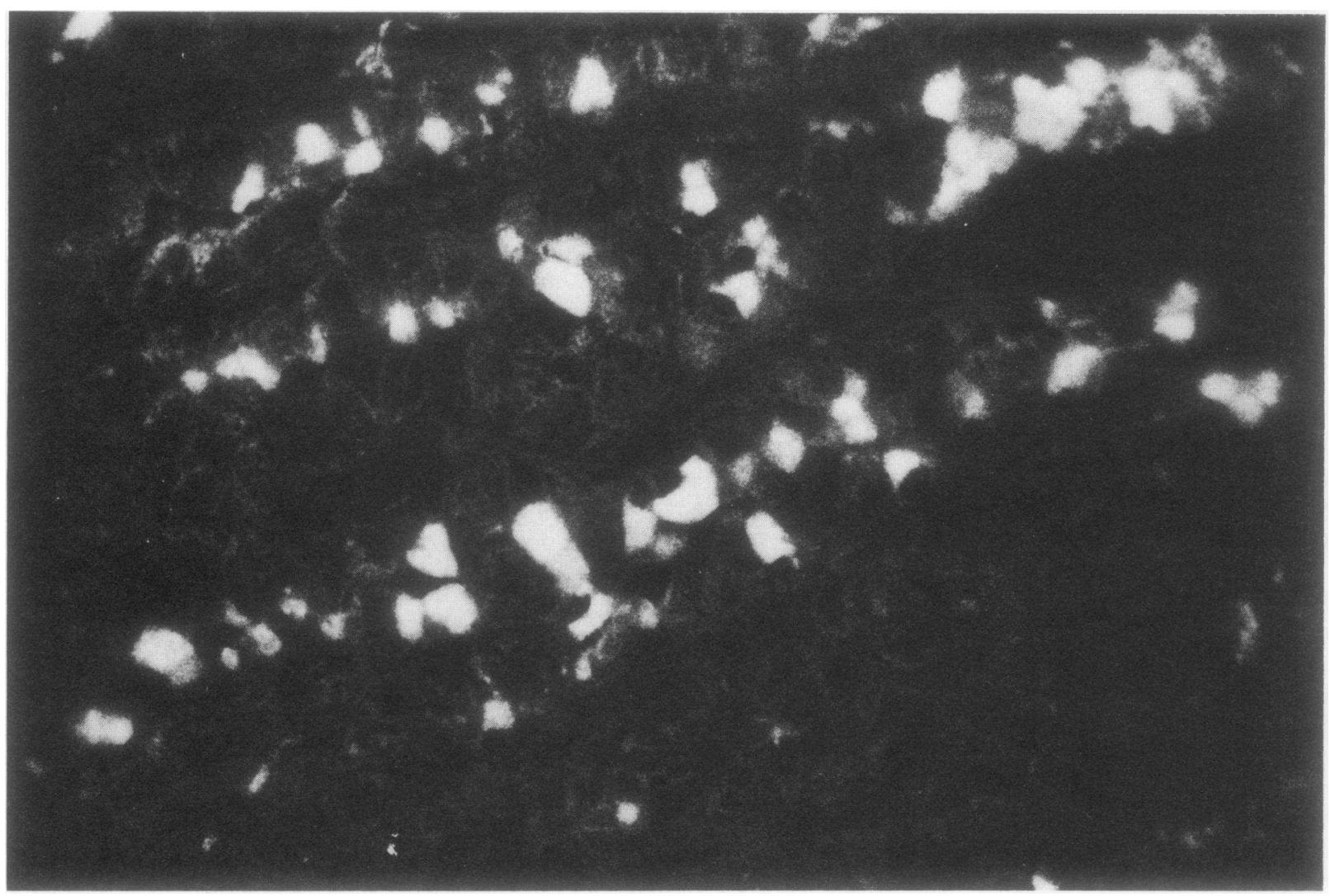

FIgURE 5 Fluorescent antibody staining. Human gastric mucosa section was stained with purified hog anti-K $\mathrm{K}^{+}$-ATPase antibody followed by fluorochrome-labeled anti-rabbit IgG. The majority of the fluorescence is confined to the middle third region of the gastric gland and primarily to the parietal cells $(\times 315)$. 


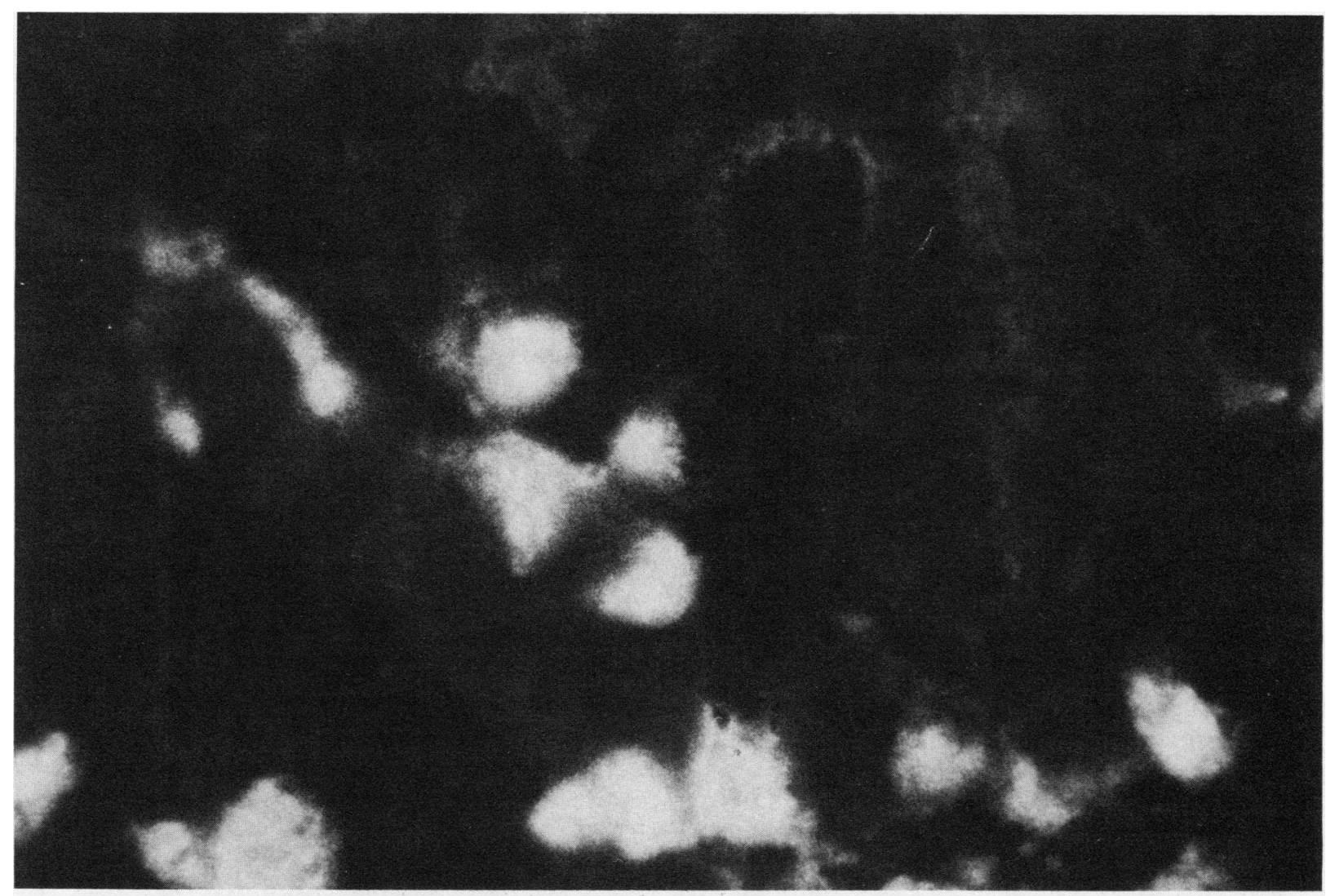

Figure 6 Fluorescence antibody staining. Human gastric mucosa section was treated as in Fig. 5. Note that the fluorescence is confined to the parietal cells as identified by their shape and location $(\times 785)$.

ous species $(12,23)$ have implicated an $\left(\mathrm{H}^{+}+\mathrm{K}^{+}\right)$-ATPase in the terminal stage of $\mathrm{H}^{+}$transport. The evidence for the role of this enzyme is $(a)$ the requirement for $\mathrm{K}^{+}$ for acid secretion $(8)$; $(b)$ the microsomal or smooth membrane localization of activity $(3,6) ;(c)$ tissue specificity of this enzyme $(11) ;^{3}(d)$ the parietal cell origin of the enzyme activity $(11) ;^{3}(e)$ the $\mathrm{H}^{+}$and $\mathrm{K}^{+}$transport capability of vesicles containing this enzyme activity $(12,14)$. The discovery and delineation of the properties of this enzyme has, for the time being, relegated the $\mathrm{HCO}_{3}^{-}$-stimulated ATPase activity to a less important role, if any (24). There remain obstacles however to acceptance of this ATPase activity as the only component of the gastric $\mathrm{H}^{+}$pump, notably the lower than theoretical $\mathrm{H}^{+}$gradient developed by gastric vesicles (25). Nevertheless it seems likely that the enzyme is involved in the primary active transport of $\mathrm{HCl}$.

In contrast, evidence has been accumulating that the other active transport component, that of $\mathrm{Cl}^{-}$, is secondary active, dependent on $\mathrm{Na}^{+}$and $\mathrm{Na}^{+}$plus $\mathrm{K}^{+}$ ATPase activity $(26,27)$ and a specific model has been suggested for transport of this ion (28).

Because of the theoretical importance and possible therapeutic implications of the $\mathrm{K}^{+}$-ATPase in accounting for acid secretion in man, the demonstration of the presence and selected properties of this enzyme in human gastric tissue is of interest.

The fractionation of human gastric tissue when carried out in a manner similar to that used for dog (5) and hog (12) mucosa gave data which were qualitatively comparable to those obtained from the above species.

The use of a density gradient centrifugation as final purification step of the human gastric microsomes yielded three classes of membranes: $\mathrm{H}_{1}$ which is 9 -fold enriched in $5^{\prime}$-nucleotidase and $\cong 18$-fold in $\mathrm{K}^{+}$ATPase; $\mathbf{H}_{2}$ which is enriched 7 -fold in $\mathrm{K}^{+}$-pNPPase and $\mathrm{H}_{3}$ which contains $>90 \%$ of the mitochondria enzyme markers and is enriched in $\mathbf{M g}^{++}-\mathrm{ATPase}$ with respect to the total homogenate. The presence of significant AMPase activity, considered to be a plasma membrane marker (29), in $\mathbf{H}_{2}$ probably indicated contamination by other membranes in this deeper fraction.

In hog, the $\mathrm{K}^{+}$-pNPPase seemed to co-purify with the $\mathrm{K}^{+}$-ATPase-containing membranes, however in man, although some degree of co-purification of these two enzymes is achieved in $\mathrm{H}_{1}$ fraction, most of the 


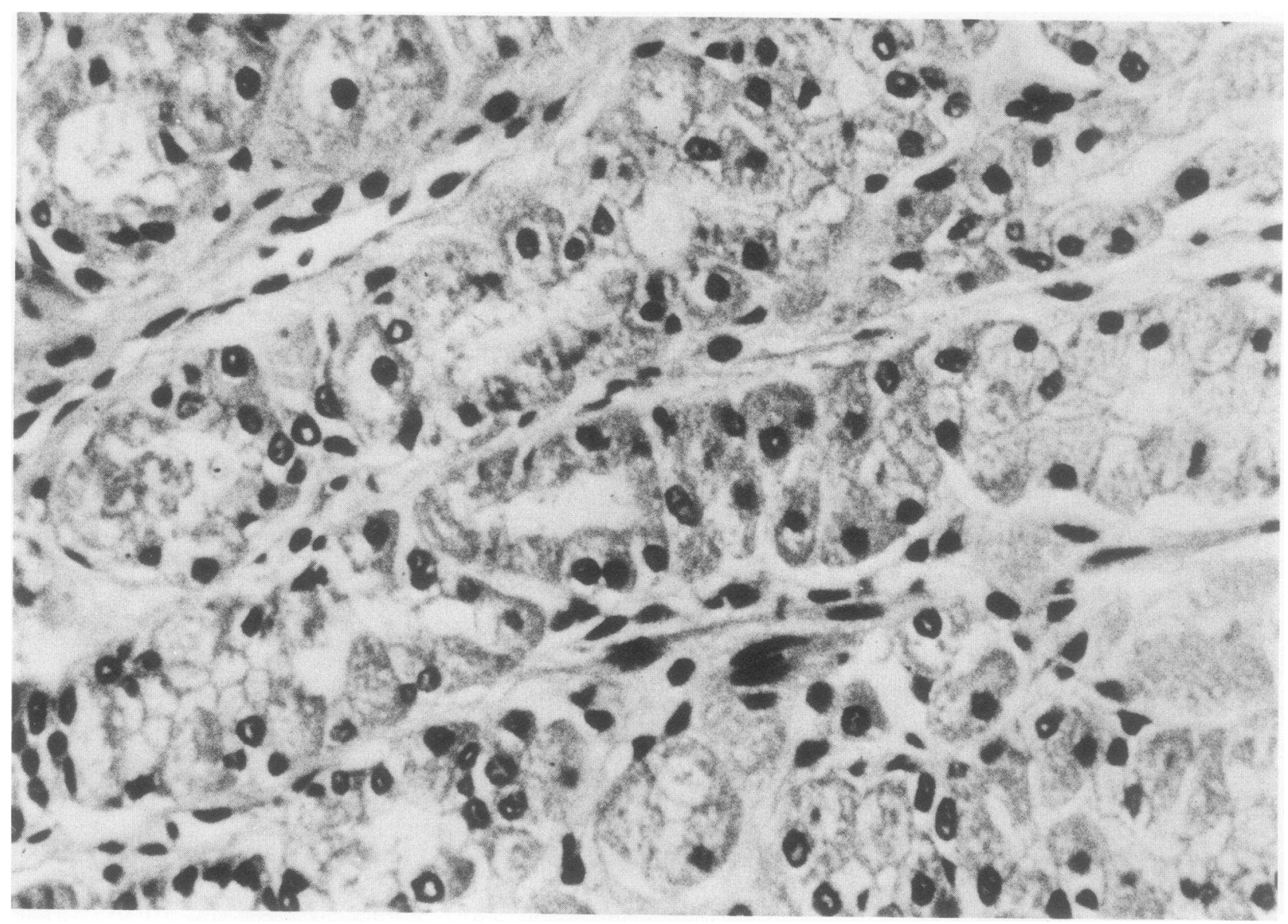

FIGURE 7 Light microscopy. Section of human gastric mucosa stained with hematoxylin and eosin showing the gastric glands inserted in the connective tissue to be compared to Fig. $5(\times 315)$.

$\mathrm{K}^{+}$-pNPPase activity is associated with $\mathrm{H}_{2}$ fraction. These results were not unusual, since $\operatorname{dog}(5)$ and rabbit (3) also show quite similar behavior.

The findings that gramicidin, in isotonic conditions, increased the $\mathrm{K}^{+}$-ATPase activity of the human gastric vesicles as shown for other species $(6,30)$ suggested that this ionophore enhanced the penetration of $\mathrm{K}^{+}$ into the interior of the vesicles, eliminating the permeability barrier. This effect appeared significantly larger in $\mathrm{H}_{1}$ fraction with about a $59 \%$ increase in $\mathrm{K}^{+}$ATPase activity when compared to the gramicidin untreated vesicles.

The polypeptide composition of the human vesicular membrane fraction seemed characteristic of all species studies thus far at this stage of purification, such as dog (5), hog (14) and frog (31) in that a major protein component is localized at $\cong 100,000$ daltons on SDS polyacrylamide gel.

It has been shown that purified gastric microsomal membranes of several other species $(4,5,21)$ possess a membrane-bound phosphorylated intermediate which appears to be closely associated with the $\mathrm{K}^{+}$-ATPase activity.
Human gastric membranes also present a similar phosphoprotein which can be dephosphorylated in the presence of $\mathrm{K}^{+}$. This protein probably corresponds to a catalytic component of the ATPase which therefore characterizes the gastric $\mathrm{H}^{+}$secretory membrane.

The finding that morphologically, the $\mathrm{K}^{+}$-ATPase active fraction is vesicular, and that ATPase activity was limited by the $\mathrm{K}^{+}$permeability of the vesicles (ionophoretic stimulation) led to the further demonstration that human gastric vesicles, as for other mammals $(12,23)$ and frog (31) are capable of developing an $\mathrm{H}^{+}$gradient upon addition of ATP. The development of this gradient was dependent on the presence of $\mathrm{K}^{+}$and its presence was further established by the effect of ionophore in reversing the external $\mathrm{pH}$ of the medium. Moreover, as for dog and hog vesicles, both $\mathrm{K}^{+}$-ionophore and protonophore were required to completely abolish the $\mathrm{H}^{+}$gradient, indicating that human vesicles have also a low $\mathrm{H}^{+}$and $\mathrm{K}^{+}$conductance. The implications of this statement have been discussed in detail elsewhere (13). The fact that in human vesicles total $\mathrm{H}^{+}$transport is reached over a 3-min period $(<1$ min for hog vesicles) and the initial $\mathrm{H}^{+}$uptake rate is 
much lower than that observed in hog vesicles, could indicate that $\mathrm{K}^{+}$permeability in human vesicles is lower than that in hog vesicles considering that $\mathrm{K}^{+}$ entry is the rate limiting step of $\mathrm{H}^{+}$transport under an inward $\mathrm{K}^{+}$gradient.

The results from the immunofluorescence studies show that human gastric tissue contains an antigenic component probably similar to that present on highly purified hog gastric membrane fractions and residing in the parietal cells.

Thus, human tissue seems to contain the same highly tissue specific $\mathrm{H}^{+}$transport enzyme found in lower species and its presence may prove to be of significance in understanding the basis of secretory pathology and for future therapeutically active agents.

\section{ACKNOWLEDGMENTS}

This work was supported in part by grants AM15818 and National Science Foundation PCM 11-19851.

\section{REFERENCES}

1. Sedar, A. W. 1965. Fine structures of the stimulated oxyntic cell. Fed. Proc. 24: 1360-1367.

2. Helander, H. F. 1976. Stereological changes in rat parietal cells after vagotomy and antrectomy. Gastroenterology. 71: 1010-1018.

3. Forte, J. G., T. M. Forte, and P. Saltman. 1967. K ${ }^{+}$-stimulated phosphatase of microsomes from gastric mucosa. J. Cell. Physiol. 69: 293-304.

4. Ray, T. K., and J. G. Forte. 1976. Studies on the phosphorylated intermediates of a $\mathrm{K}^{+}$-stimulated ATPase from rabbit gastric mucosa. Biochim. Biophys. Acta. 443: 451-467.

5. Saccomani, G., G. Shah, J. G. Spenny, and G. Sachs. 1975. Characterization of gastric mucosal membranes. VIII. The localization of peptides by iodination and phosphorylation. J. Biol. Chem. 250: 4802-4809.

6. Saccomani, G., H. B. Stewart, D. Shaw, M. Lewin, and G. Sachs. 1977. Characterization of gastric mucosal membranes. IX. Fractionation and purification of $\mathrm{K}^{+}$-ATPase containing vesicles by zonal centrifugation and free flow electrophoresis techniques. Biochim. Biophys. Acta. 465: 311-330.

7. Forte, J. G., A. Ganser, R., Beesly, and T. M. Forte. 1975. Unique enzymes of purified microsomes from pig fundic. $\mathrm{K}^{+}$-stimulated adenosine triphosphatase and $\mathrm{K}^{+}$-stimulated pNPPase. Gastroenterology. 69: 175-189.

8. Harris, J. B., and I. S. Edelman. 1960. Transport of potassium by gastric mucosa of the frog. Am. J. Physiol. 198: 282-284.

9. Berglindh, T. 1977. Effects of common inhibitors of gastric acid secretion on secretagogue-induced respiration and aminopyrine accumulation in isolated gastric glands. Biochim. Biophys. Acta. 464: 217-233.

10. Hirschowitz, B. I., and G. Sachs. 1967. Insulin inhibition of gastric secretion reversal by rubidium. Am. J. Physiol. 213: $1401-1405$.

11. Saccomani, G., S. Crago, A. A. Mihas, D. W. Dailey, and G. Sachs. 1978. Tissue and cell localization of hog gastric plasma membrane by antibody technique. Acta Physiol. Scand. Suppl. (Gastric Ion Transport). 293-305.

12. Sachs, G., H. H. Chang, E. Rabon, R. Schackmann, M. Lewin, and G. Saccomani. 1976. A non-electrogenic $\mathrm{H}^{+}$pump in plasma membranes of hog stomach. J. Biol. Chem. 251: 7690-7698.

13. Sachs, G. $1977 . \mathrm{H}^{+}$transport by a non-electrogenic gastric ATPase as a model for acid secretion. Rev. Physiol. Biochem. Exp. Pharmacol. 79: 133-162.

14. Chang, H. H., G. Saccomani, E. Rabon, R. Schackmann, and G. Sachs. 1977. Proton transport by gastric membrane vesicles. Biochim. Biophys. Acta. 464: 313-327.

15. Forte, J. G., and T. K. Ray. 1972. Method for preparing oxyntic cells from frog gastric mucosa. J. Appl. Physiol. 32: 714-717.

16. Lowry, O. H., N. J. Rosebrough, A. L. Farr, and R. J. Randall. 1951. Protein measurement with the Folin phenol reagent. J. Biol. Chem. 193: 265-275.

17. Torriani, A. 1968. Alkaline phosphatase of Escherichia coli. Methods Enzymol. 12B: 212-218.

18. King, T. E. 1967. Preparation of succinate dehydrogenase and reconstitution of succinate oxidase. Methods Enzymol. 10: 322-331.

19. Tabor, C. W., H. Tabor, and S. M. Rosenthal. 1953. Purification of amine oxidase from beef plasma. J. Biol. Chem. 208: 645-661.

20. Fairbanks, G., T. L. Steck, and D. F. H. Wallach. 1971. Electrophoretic analysis of the major polypeptides of the human erythrocyte membrane. Biochemistry. 10: 26062617.

21. Thayer, W. S., and P. C. Hinkle. 1973. Stoichiometry of adenosine triphosphate driven proton translocation in bovine heart submitochondrial particles. J. Biol. Chem. 248: 5395-5402.

22. Sainte-Marie, G. 1962. A parafilm embedding technique for studies employing immunofluorescence.J. Histochem. Cytochem. 10: 250-254.

23. Lee, J. E., G. Simpson, and P. Scholes. 1974. Change of outer $\mathrm{pH}$ in suspension of microsomal vesicles accompanying ATP hydrolysis. Biochem. Biophys. Res. Commun. 60: 825-834.

24. Kasbekar, D. K., and R. P. Durbin. 1965. An adenosine triphosphatase from frog gastric mucosa. Biochim. Biophys. Acta. 105: 472-482.

25. Rabon, E., H. H. Chang, and G. Sachs. 1978. Quantitation of $\mathrm{H}^{+}$potential gradients in gastric plasma membrane vesicles. Biochemistry. 17: 3345-3353.

26. Sachs, G., R. L. Shoemaker, and B. I. Hirschowitz. 1966. Effect of $\mathrm{Na}^{+}$removal from in vitro frog mucosa. Proc. Soc. Exp. Biol. Med. 123: 47-52.

27. Forte, J. G. 1969. Three components of $\mathrm{Cl}^{-}$flux across isolated bullfrog gastric mucosa. Am. J. Physiol. 216: 167-174.

28. Sachs, G., J. G. Spenney, and M. Lewin. 1978. $\mathrm{H}^{+}$transport. Regulation and mechanism in gastric mucosa and membrane vesicles. Physiol. Rev. 58: 106-173.

29. Benedetti, E., and P. Emmelot. 1968. The Membranes. A. J. Dalton and F. Haguenar, editors. Academic Press, Inc., New York. 33-119.

30. Ganser, A. L., and J. G. Forte. 1973. Ionophoretic stimulation of $\mathrm{K}^{+}$-ATPase of oxyntic cell microsomes. Biochem. Biophys. Res. Commun. 54: 690-696.

31. Rabon, E., G. Saccomani, D. K. Kasbekar, and G. Sachs. 1979. Transport characteristics of frog gastric membranes. Biochim. Biophys. Acta. 551: 432-447. 